\title{
Natural history of the rare and endangered snake Atractus ronnie (Serpentes: Colubridae) in northeastern Brazil
}

\author{
Cristiana Ferreira-Silva, ${ }^{1}$ Samuel Cardozo Ribeiro, ${ }^{2}$ Edna Paulino de Alcantara, ${ }^{1}$ and Robson \\ Waldemar Ávila ${ }^{3}$ \\ ${ }^{1}$ Departamento de Parasitologia, Instituto de Biociências, Universidade Estadual Paulista, Campus de Botucatu. 18080-970, \\ Botucatu, SP, Brazil. E-mail: cristianasilva006@gmail.com. \\ ${ }^{2}$ Instituto de Formação de Educadores, Universidade Federal do Cariri. 63260-000, Brejo Santo, CE, Brazil. \\ ${ }^{3}$ Departamento de Ciências Biológicas, Universidade Regional do Cariri, Campus do Pimenta. 63100-000, Crato, CE, Brazil.
}

\begin{abstract}
Natural history of the rare and endangered snake Atractus ronnie (Serpentes: Colubridae) in northeastern Brazil. The habitat use, activity period, sexual dimorphism, morphological variation, reproduction and diet composition of this fossorial and nocturnal snake are reported. The snakes were captured between 2008-2014 in the Chapada do Araripe in northeastern Brazil, and were collected by active visual searches, as well as in pitfall traps with drift fences. Although females are larger than males, the males have longer tails, and scale counts differ between the sexes. Reproduction is seasonal, occurring during the rainy season. Brood sizes rang from one to four eggs. Atractus ronnie preys on earthworms, in addition to ants (Crematogaster sp.) and insect larvae.
\end{abstract}

Keywords: Cerrado, diet, sexual dimorphism, habits, reproduction.

\begin{abstract}
Resumo
História natural da serpente rara e ameaçada de extinção Atractus ronnie (Serpentes: Colubridae) no nordeste do Brasil. $O$ uso do habitat, período de atividade, dimorfismo sexual, variações morfológicas, reprodução e a composição da dieta desta serpente fossória e noturna são relatados. As serpentes foram capturadas entre 2008-2014 na Chapada do Araripe, nordeste do Brasil, e foram coletadas por meio de busca ativa, bem como em armadilhas de queda com cerca guias. Embora as fêmeas sejam maiores que os machos, os machos têm caudas mais longas e as contagens das escamas diferem entre os sexos. A reprodução é sazonal, ocorrendo durante a estação chuvosa. O tamanho da ninhada variou de um a quatro ovos. A principal presa de A. ronnie são minhocas, além de formigas (Crematogaster sp.) e larvas de insetos.
\end{abstract}

Palavras-chave: Cerrado, dieta, dimorfismo sexual, hábito, reprodução.

Received 13 September 2018

Accepted 23 April 2019

Distributed June 2019 


\section{Introduction}

The Neotropical snake genus Atractus Wagler, 1828 is remarkably diverse, having about 150 species distributed from Panama to Argentina (Giraudo and Scrocchi 2000, Myers 2003, Passos et al. 2018). The descriptions of most species are based on only a few specimens (e.g., Passos and Fernandes 2008, Passos et al. 2010) and data on natural history are scant, owing to the secretive habits of the snakes (cryptozoic and semi-fossorial) and localized endemism. This has contributed to the small sample sizes reported by many authors (e.g., Martins and Oliveira 1993, Cisneros-Heredia 2005, Sawaya et al. 2008, Barbo et al. 2011).

Atractus ronnie Passos, Fernandes, and Borges-Nojosa, 2007 is endemic to the Caatinga Biome where it inhabits highland marshes in the Brazilian state of Ceará (Guedes et al. 2014). The taxon was first described for the Serra de Baturité Mountains (Passos et al. 2007), but the range also includes the Ibiapaba and Araripe Plateaus (Loebmann et al. 2009). Atractus ronnie is a federally threatened species, cataloged as Endangered (EN) (MMA 2014). In the Chapada do Araripe, A. ronnie is found only in a narrow strip of rainforest on the slopes (Ribeiro et al. 2012). Biological data on the species are scarce, with little information available other than the original description (Passos et al. 2007). Herein, we provide data on substrate use, activity period, sexual dimorphism, morphological variation, reproduction and diet of $A$. ronnie at the Chapada do Araripe in northeastern Brazil.

\section{Materials and Methods}

\section{Study Area}

The Chapada do Araripe is located in three states (Ceará, Piauí, and Pernambuco) in northeast Brazil (Lima et al. 2012). The altitude varies from $500-1100 \mathrm{~m}$ a.s.l. On the slopes, the vegetation is humid forest (tropical cloud forest) and dry forest (semideciduous forest), with Cerrado, Cerradão (xeromorphic semideciduous forest), and Carrasco phytophysiognomies at the top (Tabarelli and Santos 2004). The climate is tropical-i.e., wet and hot with a rainy season from December-May. The mean annual precipitation is $1090 \mathrm{~mm}^{3}$ and the mean temperature is $24-26^{\circ} \mathrm{C}$ (IPECE 2016).

We carried out fieldwork monthly at two sites on the slopes of the Chapada do Araripe, in the municipality of Crato, Ceará state. The first site was Delvechia ranch $\left(07^{\circ} 15^{\prime} 19^{\prime \prime} \mathrm{S}, 39^{\circ} 28^{\prime} 12^{\prime \prime}\right.$ W; datum WGS 84; 729 m a.s.1.) between March 2008 and February 2010. The second was the Ecological Trail of the Clube Recreativo Granjeiro $\left(07^{\circ} 16^{\prime} 47.0^{\prime \prime} \mathrm{S}, 39^{\circ} 26^{\prime} 17.7^{\prime \prime} \mathrm{W}\right.$; datum WGS 84; $691 \mathrm{~m}$ a.s.1.) between September 2011 and August 2012 and January-December 2014. These sites are located in a narrow band of humid forest within the boundaries of the Araripe Environmental Protection Area (APA Araripe; Figure 1).

\section{Data Collection}

We found the snakes by active, visualencounter searches by day and by night, and by pitfall traps with drift fences (Table 1). For specimens that we collected by active searches, we recorded the time of capture and the substrate on which the snake was first seen. We took the specimens to the Laboratório de Herpetologia da Universidade Regional do Cariri, where they were euthanized with an intraperitoneal injection of sodium thiopental $50 \mathrm{mg} / \mathrm{kg}$ as per the permits issued by the Comitê de Ética em Pesquisa of the Universidade Regional do Cariri. The specimens were fixed with $10 \%$ formalin and preserved in $70 \%$ ethanol. Voucher specimens are deposited in the Coleção Herpetológica da Universidade Regional do Cariri (URCA-H 149-158, 62036204, 10067, 10131-10132, 10261-10264, 10266, 10271, 10540, 10606, 10608-10609, 10656, 11019-11020) and in the Coleção Herpetológica da Universidade Federal de Pernambuco (CHUFPE 99 and 100). 


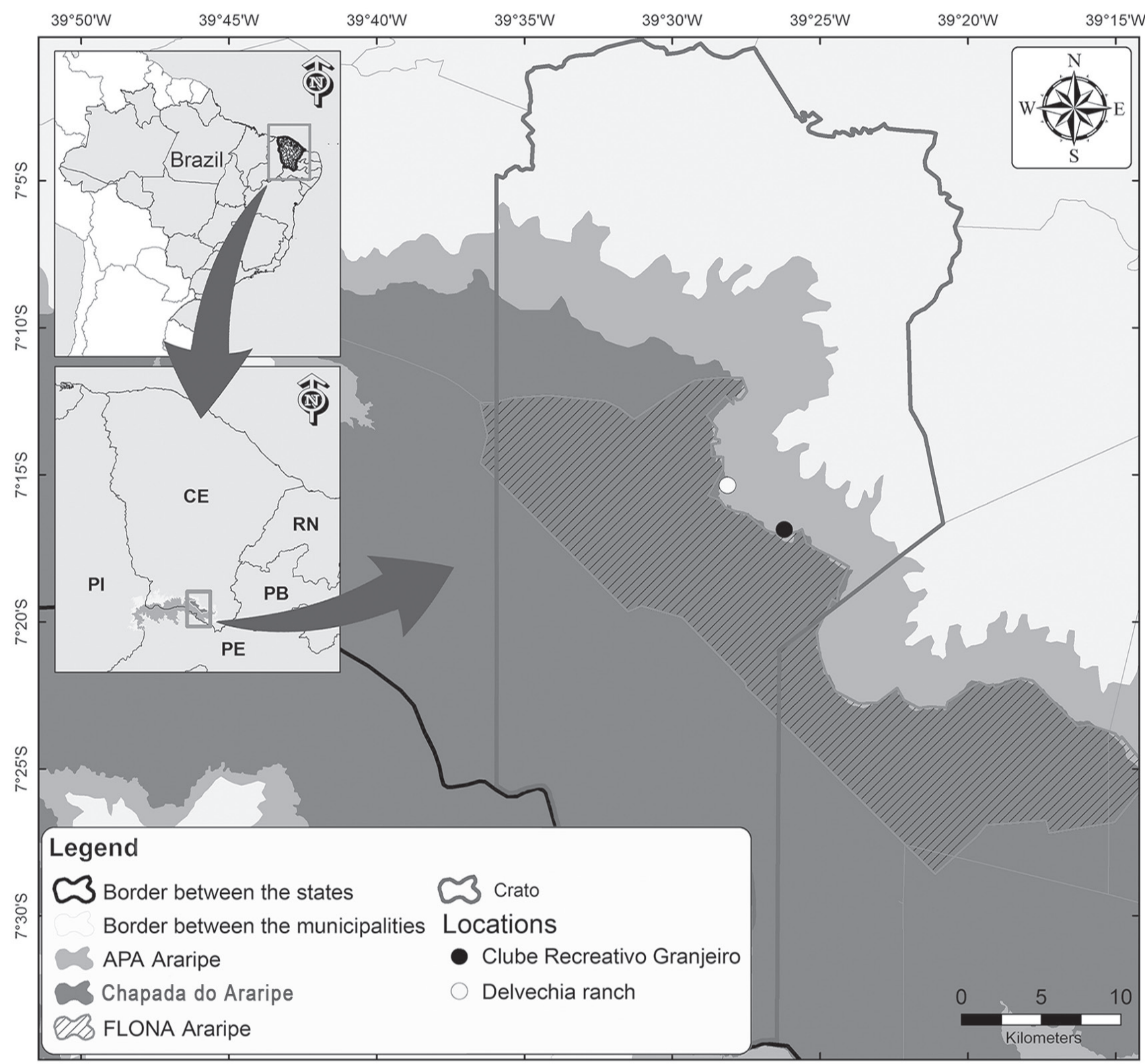

Figure 1. Study area in the Chapada do Araripe, Ceará state, northern Brazil. APA Araripe = Araripe Environmental Protection Area, FLONA Araripe = Araripe National Forest. Legend to Brazilian states: CE, Ceará; PB, Paraíba; PE, Pernambuco; PI, Piauí; RN, Rio Grande do Norte.

\section{Data Analysis}

We examined a total of 30 Atractus ronnie (Figure 2). For each specimen we recorded the following morphometric variables with digital calipers to the nearest $0.01 \mathrm{~mm}$ : snout-vent length (SVL); head length (HL); head width (HW); head height (HH); and tail length (TL). We also counted ventral and subcaudal scales and dorsal scale rows (in 3 regions of the body-i.e., counted one head length from the neck, the middle of the body and one head length from the cloaca) (Peters 1964). Males were considered reproductively active if they possessed convoluted deferent ducts (Shine 1988). Females were considered reproductively active if they possessed 
Table 1. Details of sampling methods used in the collection of Atractus ronnie at Chapada do Araripe, northeastern Brazil between 2008 and 2014.

\begin{tabular}{|c|c|c|c|c|c|c|}
\hline Locality & Period & $\begin{array}{l}\text { Sampling } \\
\text { protocol }\end{array}$ & $\begin{array}{l}\text { Total } \\
\text { days in } \\
\text { the field }\end{array}$ & $\begin{array}{l}\text { Description of the } \\
\text { sampling method }\end{array}$ & Total effort & $\begin{array}{l}\text { Number specimens } \\
\text { collected during study }\end{array}$ \\
\hline $\begin{array}{l}\text { Delvechia } \\
\text { Ranch }\end{array}$ & $\begin{array}{l}\text { Mar } \\
2008- \\
\text { Feb } \\
2010\end{array}$ & $\begin{array}{l}\text { Pitfall traps } \\
\text { with drift } \\
\text { fences }\end{array}$ & 60 & $\begin{array}{l}5 \text { arrays ( } 4 \text { buckets } \\
20 \mathrm{~L} \text { per array) Y } \\
\text { shape; } 5 \text { days, bi- } \\
\text { monthly collection }\end{array}$ & $\begin{array}{l}1.200 \\
\text { buckets- } \\
\text { day }\end{array}$ & $\begin{array}{l}\text { March } 2008(N=9) ; \\
\text { February } 2010(N=1)\end{array}$ \\
\hline \multirow{3}{*}{$\begin{array}{l}\text { Ecological } \\
\text { trail of } \\
\text { the Club } \\
\text { Recreativo } \\
\text { Granjeiro }\end{array}$} & $\begin{array}{l}\text { Sep } \\
2011- \\
\text { Aug } \\
2012\end{array}$ & $\begin{array}{l}\text { Active } \\
\text { searches }\end{array}$ & 12 & $\begin{array}{l}1 \text { day per mo; } 1 \text { hr } \\
\text { per day; } 4 \text { collectors }\end{array}$ & $\begin{array}{l}48 \mathrm{hr}- \\
\text { collector }\end{array}$ & $\begin{array}{c}\text { March }(N=1) ; \\
\text { June }(N=1) \text { in diet of } \\
\text { Bothrops leucurus }\end{array}$ \\
\hline & \multirow{2}{*}{$\begin{array}{c}\text { Jan-Dec } \\
2014\end{array}$} & $\begin{array}{l}\text { Pitfall traps } \\
\text { with drift } \\
\text { fences }\end{array}$ & 365 & $\begin{array}{l}5 \text { arrays (8 buckets } \\
60 \mathrm{~L} \text { per array) straight } \\
\text { line }\end{array}$ & $\begin{array}{l}14.600 \\
\text { buckets- } \\
\text { day }\end{array}$ & $\begin{array}{c}\text { January }(N=3) ; \text { February } \\
(N=5) ; \text { May }(N=1) ; \\
\text { December }(N=2)\end{array}$ \\
\hline & & $\begin{array}{l}\text { Active } \\
\text { searches }\end{array}$ & 48 & $\begin{array}{l}4 \text { days per mo/ } 3 \mathrm{hr} \\
\text { per day; } 2 \text { collectors }\end{array}$ & $\begin{array}{l}288 \mathrm{hr}- \\
\text { collector }\end{array}$ & $\begin{array}{l}\text { October }(N=1) ; \\
\text { November }(N=5) ; \\
\text { December }(N=1)\end{array}$ \\
\hline
\end{tabular}

flaccid oviducts, ovarian follicles in secondary vitellogenesis (> $4 \mathrm{~mm}$ long) or oviductal eggs (modified from Shine 1988); the simultaneous presence of both vitellogenic follicles and eggs was considered evidence of production of more than one clutch per season (Shine 1977, Fitch 1982). We recorded the number of eggs and/or follicles, as well as the lengths and widths of eggs, follicles, and testicles, and estimated their volumes using the ellipsoid formula: $V=(4 \pi / 3)$ $(W / 2)^{2}(L / 2)$, in which $W$ and $L$ represent width and length, respectively (e.g., Sousa and Ávila 2015).

We calculated the sexual size dimorphism index (SSD) following Shine's (1994) method in which the mean body size of the larger sex is divided by the mean body size of the smaller sex, minus one. Positive values represent females larger than males, and negative values represent the converse (Shine 1994). We used a MannWhitney U test to examine intersexual differences in adult SVL, and tested sexual dimorphism in relation to $\mathrm{HL}, \mathrm{HW}, \mathrm{HH}$, and $\mathrm{TL}$ using an ANCOVA with SVL as covariate. We used Student's t-test to examine dimorphism ventral and subcaudal scales in adults. To determine if there is a correlation between SVL and testicle volume and between SVL and egg volume, we used the parametric correlation of Pearson. Descriptive statistical analyses used throughout the paper include means followed by \pm SD. We conducted all tests with 1.26 PAST software (Hammer et al. 2001), using a 5\% significance level.

We dissected each specimen and analyzed stomach contents, identifying the prey to the most precise taxonomic category possible.

\section{Results}

\section{Substrate Use and Activity Period}

During active searches we observed eight individual Atractus ronnie. Four were inactive at 07:15 to $09: 51 \mathrm{~h}$ and found under fallen logs (2 in November and 1 in December) or buried 10 cm deep in soil loosened by roots (1 in October). The other four were active at 19:26 and 20:22 h and found on the ground (1 in November), in leaf litter ( 2 in November), and under a fallen 


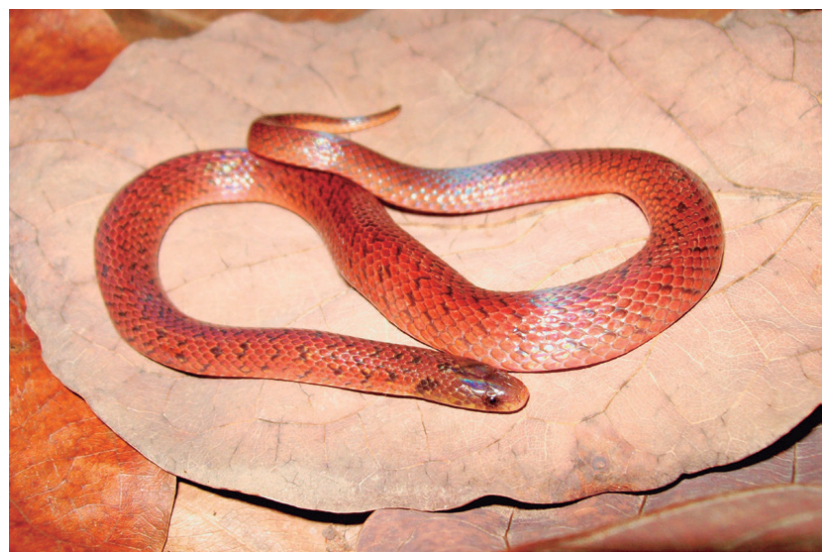

Figure 2. Atractus ronnie at Chapada do Araripe, northeastern Brazil.

$\log$ in moist soil (1 in March). Twenty-one snakes were captured in pitfall traps and one individual was found in the stomach of a Bothrops leucurus Wagler, 1824 (Ferreira-Silva et al. 2015) (Table 1).

\section{Sexual Dimorphism}

There is significant sexual dimorphism in the tail and snout-vent lengths and the head width of Atractus ronnie. Females have a longer SVL ( $U$ $=4.20, p<0.001 ; \mathrm{SSD}=0.23)$ and a wider head $\left(F_{1,24}=21.23, p<0.001\right)$. However, males have longer tails $\left(F_{1,24}=84.06, p<0.001\right)$ (Table 2). Likewise, there is sexual dimorphism in the numbers of ventral and subcaudal scales with females having more ventrals (mean $=142.1 \pm$ $7.3 ; 139-155)$ than males $($ mean $=135.2 \pm 3.5$;
$132-143 ; t=8.29 ; p<0.001)$, and males having more subcaudals (mean $=23.4 \pm 1.1 ; 22-25$ ) than females $($ mean $=21.2 \pm 2.6 ; 18-21 ; t=$ $8.39 ; p<0.001)$. There are three patterns of dorsal scale rows-viz., 17-17-17; 15-17-17; 1515-15 (Table 3).

\section{Reproduction}

The smallest sexually active female was $217.1 \mathrm{~mm}$ SVL, whereas the smallest sexually active male was $169.4 \mathrm{~mm}$ SVL. We recorded four females with eggs-one in January and three in March. The clutch size varies from 1-4 eggs (mean volume $\pm \mathrm{SD}=222.7 \pm 38.9$; 167.6$\left.250.3 \mathrm{~mm}^{3} ; N=10\right)$; there is no correlation between SVL and egg volume $(\mathrm{r}=-0.06, \mathrm{p}=$ $0.9)$. Only one female collected in March had oviductal eggs (mean volume $\pm \mathrm{SD}=250.1 \pm$ $\left.16.6 ; 234.7-267.6 \mathrm{~mm}^{3} ; N=3\right)$. We collected six females with follicles in secondary vitellogenesis-one in February and five in March; the number of these follicles varied from three to seven (mean length $\pm \mathrm{SD}=7.3 \pm 2.2$ $\mathrm{mm}$, range $=4.7-11.8 \mathrm{~mm}$; mean volume $\pm \mathrm{SD}$ $=21.1 \pm 16.9 \mathrm{~mm}^{3}$, range $=4.9-49.2 \mathrm{~mm}^{3} ; N=$ 26). Egg laying is coincident with the rainy season (Figure 3). We recorded juveniles in November $(N=3)$ with one juvenile female having a SVL of $94 \mathrm{~mm}$ and two juvenile males with SVLs of 125.2 and $136.6 \mathrm{~mm}$, respectively. The mean volume of the testicles of adult males was $10.1 \pm 3.8 \mathrm{~mm}^{3}$ with a range of $4.5-17.5$

Table 2. Morphometrics of adult female and male Atractus ronnie (mean \pm standard deviation; and range) and sexual dimorphism. SVL = snout-vent length, $\mathrm{TL}=$ tail length, $\mathrm{HL}=$ head length, $\mathrm{HW}=$ head width, $\mathrm{HH}=\mathrm{head}$ height. Statistically significant results in bold.

\begin{tabular}{lccc}
\hline Variable & Females $(\mathbf{N}=\mathbf{1 1})$ & Males $(\mathbf{N}=\mathbf{1 5})$ & Statistical results \\
\hline $\mathrm{SVL}$ & $249.1 \pm 21.9 ; 217.1-289.2$ & $201.8 \pm 14.8 ; 169.4-230.0$ & $U=4.20, \boldsymbol{p}<\mathbf{0 . 0 0 1}$ \\
$\mathrm{TL}$ & $23.4 \pm 3.2 ; 18.6-29.4$ & $26.8 \pm 2.3 ; 22.9-31.0$ & $F_{1,24}=84.06, \boldsymbol{p}<\mathbf{0 . 0 0 1}$ \\
$\mathrm{HL}$ & $11.2 \pm 0.8 ; 9.6-12.4$ & $10.9 \pm 0.6 ; 9.4-11.7$ & $F_{1,24}=3.91, p=0.06$ \\
$\mathrm{HW}$ & $6.0 \pm 0.4 ; 5.5-6.6$ & $5.6 \pm 0.5 ; 5.0-6.7$ & $F_{1,24}=21.23, \boldsymbol{p}<\mathbf{0 . 0 0 1}$ \\
$\mathrm{HH}$ & $4.4 \pm 0.3 ; 3.6-4.7$ & $4.1 \pm 0.5 ; 3.3-5.4$ & $F_{1,24}=9.17, p=0.99$ \\
\hline
\end{tabular}


Table 3. Variation in the number of dorsal scale rows (DO), ventrals (VE), and subcaudals (SC) of Atractus ronnie from Chapada do Araripe, Serra de Baturité (Passos et al. 2007) and Planalto da Ibiapaba (Loebmann et al. 2009), northeastern Brazil.

\begin{tabular}{lccccc}
\hline & \multicolumn{2}{c}{ Baturité } & Ibiapaba & Araripe \\
\cline { 2 - 6 } & Males & Females & Females & Males & Females \\
\hline$N$ & 14 & 11 & 1 & 17 & 13 \\
DO & 17 & 17 & 17 & $17-17-17(N=2)$ & $17-17-17(N=5)$ \\
& & & $15-17-17(N=12)$ & $15-17-17(N=8)$ \\
VE & $134-144$ & $154-160$ & $163-15(N=3)$ & $15-15-155$ \\
SC & $20-25$ & $17-20$ & 23 & $22-25$ & $18-21$ \\
\hline
\end{tabular}

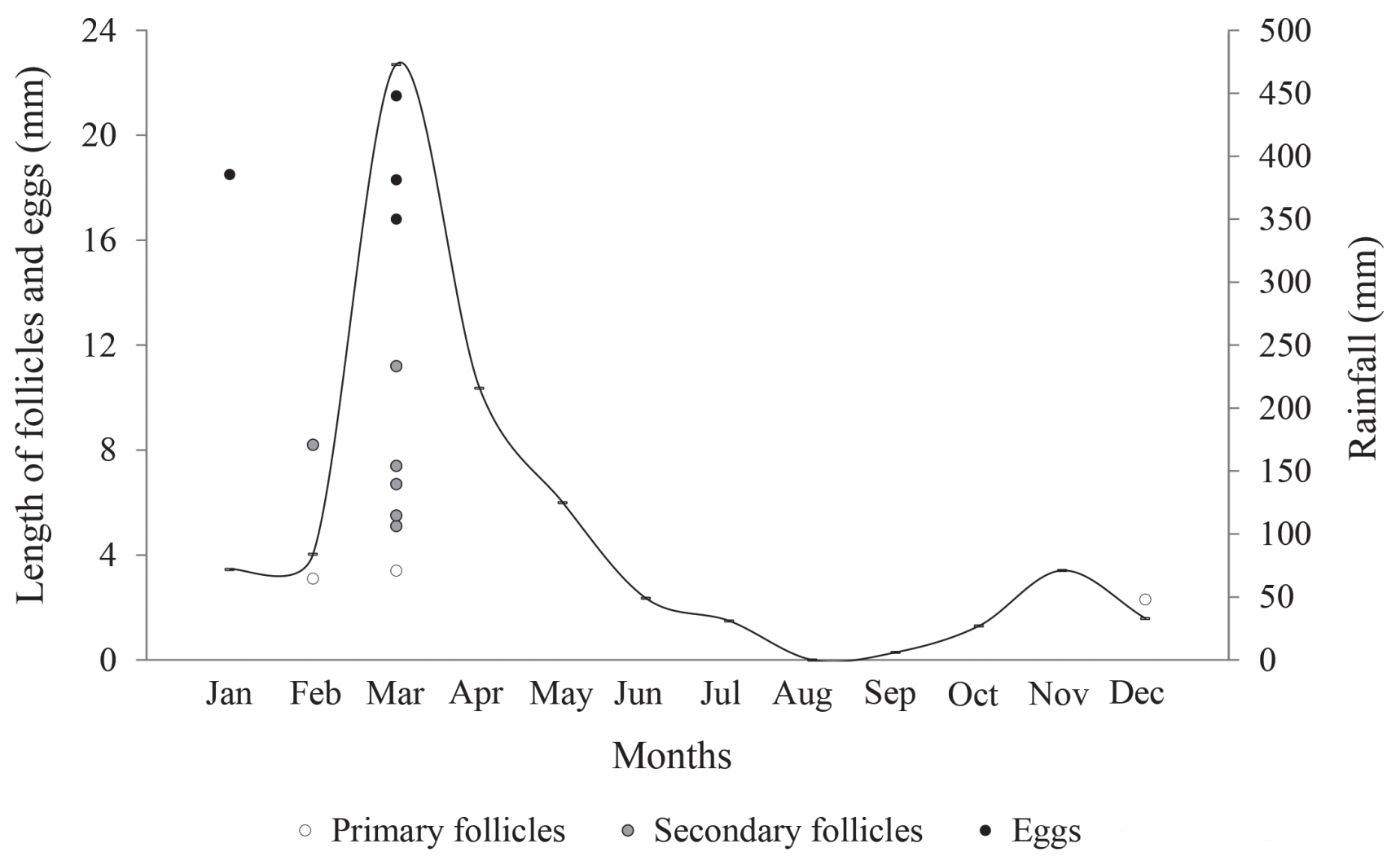

Figure 3. Variation in the length of the largest follicles and eggs of mature females of Atractus ronnie and mean monthly rainfall in Crato municipality, Ceará, between 2008 and 2014 (FUNCEME 2014) in the Chapada do Araripe, northeastern Brazil.

$\mathrm{mm}^{3}$. There is no correlation between SVL and testicular volume $(p=0.4)$. The greatest testicular volume of adult males was recorded in November at $17.5 \mathrm{~mm}^{3}$ and the least was recorded in February at $4.5 \mathrm{~mm}^{3}$.
Diet

Of the 30 Atractus ronnie examined, only 12 (40\%) had stomach contents. Earthworms (Oligochaeta) were the most common prey, 
representing $84.6 \%$ of the 13 recorded items in 11 A. ronnie. Most of the earthworms were decomposed, with only the bristles or small parts of the earthworms being visible; the one intact earthworm was $14.7 \mathrm{~mm}$ long. One snake had ingested only one ant (Crematogaster sp.) and one unidentified insect larvae $(7.7 \%$ each of the total items).

\section{Discussion}

The seasonal variation in abundance of Atractus ronnie has also been observed in other species of Atractus (Balestrin and Di-Bernardo 2005, Resende and Nascimento 2014). Abundance in the rainy season may be related to reproductive activities when the snakes are moving near the surface of the soil (e.g., males seeking females for mating and females looking sites for thermoregulation and oviposition) (Resende and Nascimento 2014). It also may coincide with higher prey availability (Sawaya et al. 2008), and/or other environmental factors (e.g, increase of humidity and temperature; Lillywhite 1987, Resende and Nascimento 2014).

Species of Atractus have been reported as nocturnal, or diurnal and nocturnal (Martins and Oliveira 1993, 1998, Marques et al. 2004, Barbo et al. 2011, Santos-Costa et al. 2015, Passos et al. 2016). In a study on the Ibiapaba Plateau, Passos et al. (2007) stated that A. ronnie was active at various hours during the day, and were observed in the field in almost all months of the year, but the snakes were seen more frequently in the rainy season (December-April). In contrast to the observtions of Passos et al. (2007), we only observed $A$. ronnie to be active at night.

The sexual dimorphism in SVL and tail length observed in Atractus ronnie is characteristic of other species in the genus (Savage 1960, Passos et al. 2005, 2007, 2016, Zaher et al. 2005). The SSD found here was positive, and although slightly greater, resembles that of A. reticulatus (Boulenger, 1885) (Balestrin and Di-Bernardo 2005) and other snakes from the tribe Dipsadini (Pizzatto et al. 2007). Usually, females are larger than males in species in which male-male combat does not occur (Shine 1978, 1984). There is no record of male-male combat in A. ronnie or its congeners; thus, the pattern we report is expected. The larger size of females may be linked to their reproductive success because larger females may produce more, larger eggs; in addition, larger females may ingest larger prey thereby ensuring greater energy reserves for reproduction (Shine 1986, 1991). Males tend to have longer tails associated with the presence of muscles related to copulatory organ located in the base of the tail (Klauber 1972, King 1989). The dimorphism in snoutvent and caudal lengths also is reflected in segmental counts (Savage 1960, Passos et al. 2005), and this correlation is well known in other Atractus (Passos et al. 2005, 2010).

Moreover, we observed significant sexual dimorphism in head length, with females having larger heads than males. According to Pagel and Harvey (1989), the evolutionary increase in body size dimorphism usually is accompanied by an increase in the degree of dimorphism in relative head size-as we observed in A. ronnie. However, Shine (1991) suggested that the increase in female head size might reflect a higher food intake to support the higher energetic expenditure on reproduction by this sex. Owing to the decomposition of the stomach contents we recovered, it was not possible to compare the sizes of the prey ingested by males and females.

We found additional variation in scale counts, mostly in dorsal scales, than that reported by Passos et al. (2007) and Loebmann et al. (2009). Thus, ventral scales in $A$. ronnie should be considered 139-163 in females and 129-144 in males. The most frequent pattern $(67 \%)$ of dorsal scale rows in the population of Chapada do Araripe was 15-17-17, in contrast to the findings of Passos et al. (2007).

At maturity, female A. ronnie are about $30 \%$ larger than males, which is consistent with findings for other members of the genus (Balestrin and Di-Bernardo 2005, Resende and 
Nascimento 2014) except A. potschi Fernandes, 1995 (Passos et al. 2016). Atractus ronnie reproduces seasonally; recruitment begins at the end of the dry season preceding the rainy season (November), and secondary vitellogenesis, pregnancy, and oviposition occurs in the rainy season (January-March). Seasonal reproduction also was observed in other species of the genus, such as A. reticulatus in southern (Balestrin and Di-Bernardo 2005) and A. pantostictus Fernandes and Puorto, 1993 in southeastern Brazil (Resende and Nascimento 2014), and it has been suggested for A. potschi (Passos et al. 2016). Martins and Oliveira (1993) speculated that Amazonian populations of $A$. latifrons (Günther, 1868) and A. torquatus (Duméril, Bribon, and Duméril, 1854) might reproduce throughout the year. Reproductive cycles in reptiles are known to vary in response to climate stability; thus, species in seasonal environments (e.g., Caatinga and Cerrado) tend to concentrate reproduction in favorable periods, whereas species in aseasonal environments do not (Fitch 1982). According to Brown and Shine (2006) females tend to lay eggs at the rainy season, when the higher soil moisture is appropriate to embryogenesis.

We observed oviducal eggs in Atractus ronnie in March and juveniles with obvious umbilical scars indicating that hatching of eggs occurred recently in November. Thus, oviposition may occur in March-April, and the incubation period may extend to November. Long incubation periods were reported for congeners, such as $A$. pantostictus with 5-8 mo of incubation (Fernandes and Puorto 1993, Cardoso and Maia 2012) and A. reticulatus with 8 mo of incubation (Fernandes and Puorto 1993).

Testicular volumes were higher at the end of the dry season preceding the rainy season (November), thereby allowing mating period to occur during the early rainy season. Resende and Nascimento (2014) also reported that the mating period of $A$. pantostictus occurs early in the rainy season.

Clutch size in Atractus ronnie varies from one to four eggs, and this is associated with the small body size. Congeners with similar SVLs also have small clutch sizes-e.g., $A$. pantostictus, 3-5 eggs, mean $=378.4 \mathrm{~mm}$ SVL, $N=5$ : Barbo et al. 2011, Cardoso and Maia 2012; A. reticulatus, $1-3$ eggs, mean $=307.8$ mm SVL, $N=5$ : Balestrin and Di-Bernardo 2005, Barbo et al. 2011; A. carrioni Parker, 1930, 3-5 eggs, $363 \mathrm{~mm}$ SVL, $N=2$; Passos et al. 2013; and A. schach (Boie, 1827), 5 eggs, $418 \mathrm{~mm}$ SVL, $N=1$ : Martins and Oliveira 1993. Larger Atractus have more eggs-e.g., A. francoi Passos, Fernandes, Bérnils, and MouraLeite, 2010, 6 eggs, $473 \mathrm{~mm}$ SVL, $N=$ 1: Marques et al. 2004; A. gigas Myers and Schargel, 2006, 12 eggs, $760 \mathrm{~mm}$ SVL, $N=$ 1: Passos et al. 2010; A. guentheri (Wucherer, 1861), 6 eggs, $427 \mathrm{~mm} \mathrm{SVL}, N=1$ : Filadelfo et al. 2013; A. major Boulenger, 1894, 6-12 eggs, $627 \mathrm{~mm} \mathrm{SVL}$ of the female with six eggs, $N=$ 2: Duellman 1978, Martins and Oliveira 1993; A. snethlageae Cunha and Nascimento, 1983, 3-9 eggs, no available SVL: Cunha and Nascimento 1983, Martins and Oliveira 1998; and A. torquatus, 3-8 eggs, mean $=693 \mathrm{~mm}$ SVL, $N=3$ : Martins and Oliveira 1993.

Atractus ronnie feeds mostly on earthworms, as do most of its congeners (Pérez-Santos and Moreno 1990, Martins and Oliveira 1993, 1998, Balestrin et al. 2007, Sawaya et al. 2008, Barbo et al. 2011). Consumption of ants and insect larvae may be secondary and/or incidental. Pérez-Santos and Moreno (1990) considered ants and other arthorpods found in the stomach of $A$. badius (Boie, 1827) to be secondary ingestions, because these items also were found in the diet of intact earthworms. Martins and Oliveira (1993, 1998) and Bernarde and Abe (2010) found acari and insect remains in the hindgut of other Atractus [A. latifrons, A. major, A. poeppigi (Jan, 1862), A. schach, and A. torquatus], which prey mainly on Oligochaeta.

By way of summary, the population of $A$. ronnie at Chapada do Araripe is diurnal and sexually dimorphic, with females having larger bodies and heads than males, and males having longer tails than females. These traits are 
reflected in the counts of ventral and caudal scales. Three distinct patterns of dorsal scales occur in the population of A. ronnie-viz., 15$15-15,15-17-17$ and 17-17-17. The species reproduces seasonally in the rainy season. Members of the population are specialize on earthworms for food. The data presented should aid in the establishment of management programs for this endemic and endangered snake to assure the continued existence of its populations.

\section{Acknowledgments}

The Instituto Chico Mendes de Conservação da Biodiversidade-ICMBio provided collecting permits (SISBIO No 44910-1; 20388-1), as did the Comitê de Ética em Pesquisa of the Universidade Regional do Cariri for permits (00026/2015). We thank Pedro Nunes curator of the Coleção Herpetológica da Universidade Federal de Pernambuco (CHUFPE) for loaning us specimens of Atractus ronnie. R.W. Ávila is indebted to the Conselho Nacional de Desenvolvimento Científico e Tecnológico $(\mathrm{CNPq})$ for providing a research fellowship (Process \# 303622/2015-6; 305988/2018-2) and financial support (Process \# 475107/2011-0). C. FerreiraSilva thanks Coordenação de Aperfeiçoamento de Pessoal de Nível Superior (CAPES) for a master fellowship. S. C. Ribeiro thanks Fundação Cearense de Apoio ao Desenvolvimento Científico e Tecnológico (FUNCAP: BPI4367050/2018). We are grateful to H. F. Oliveira for preparing the map and figure of Atractus ronnie.

\section{References}

Balestrin, R. L. and M. Di-Bernardo. 2005. Reproductive biology of Atractus reticulatus (Boulenger, 1885) (Serpentes, Colubridae) in southern Brazil. Herpetological Journal 15: 195-199.

Balestrin, R. L., M. Di-Bernardo, and A. G. Moreno. 2007. Feeding ecology of the neotropical worm snake Atractus reticulatus in southern Brazil. The Herpetological Journal 17: 62-64.
Barbo, F. E., O. A. V. Marques, and R. J. Sawaya. 2011. Diversity, natural history, and distribution of snakes in the municipality of São Paulo. South American Journal of Herpetology 6: 135-160.

Bernarde, P. S. and A. S. Abe. 2010. Hábitos alimentares de serpentes em Espigão do Oeste, Rondônia, Brasil. Biota Neotropica 10: 167-173.

Brown, G. P. and R. Shine. 2006. Why do most tropical animals reproduce seasonally? Testing hypotheses on an Australian snake. Ecology 87: 133-143.

Cardoso, S. R. T. and D. C. Maia. 2012. Clutch size and incubation period of Atractus pantostictus (Fernandes \& Pourto, 1993) (Serpentes: Dipsadidae). Biologia Geral e Experimental 12: 5-6.

Cisneros-Heredia, D. F. 2005. Report of molluscivory in Atractus carrioni Parker, 1930. Herpetozoa 18: 185186.

Cunha, O. R. and F. P. Nascimento. 1983. Ofídeos da Amazônia XX: as espécies de Atractus Wagler, 1828 na Amazônia oriental e Maranhão (Ophidia: Colubridae). Boletim do Museu Paraense Emílio Goeldi 123: 1-38.

Duellman, W. E. 1978. The biology of an equatorial herpetofauna in Amazonian Ecuador. University of Kansas, Museum of Natural History, Miscellaneous Publications 65: 1-352.

Fernandes, R. and G. Puorto. 1993. A new species of Atractus from Brazil and the status of A. guentheri (Serpentes: Colubridae). Memórias do Instituto Butantan 55: 7-14.

Ferreira-Silva, C., E. P. Alcantara, H. F. Oliveira, C. S. L. Matias, and R. W. Ávila. 2015. Bothrops leucurus (Whitetail Lancehead). Diet. Herpetological Review 46: 637.

Filadelfo, T., M. Camardelli, and R. O. Abreu. 2013. Atractus guentheri (Günther's Ground Snake). Reproduction. Herpetological Review 44: 151.

Fitch, H. S. 1982. Reproductive cycles in Tropical Reptiles. Occasional Papers of the Museum of Natural History University of Kansas 96: 1-53.

FUNCEME (Fundação Cearense de Meteorologia e Recursos Hídricos). 2014. Séries Históricas. Eletronic Database accessible at http://www.funceme.br/produtos/script/ chuvas/ Download_de_series_ historicas/downloadHis toricos/postos/605.txt. Captured on 07 December 2015.

Giraudo, A. R. and G. J. Scrocchi. 2000. The genus Atractus (Serpentes: Colubridae) in north-eastern Argentina. Herpetological Journal 10: 81-90. 
Guedes, T. B., C. Nogueira, and O.A.V. Marques. 2014. Diversity, natural history, and geographic distribution of snakes in the Caatinga, Northeastern Brazil. Zootaxa 3863: 1-93.

Hammer, Ø., D. A. T. Harper, and P. D. Ryan. 2001. PAST. Paleontological Statistics Software Package for Education and Data Analysis. Paleontologia Electronica 4. URL: http://palaeo-electronica.org/2001_1/past/ issue1_01.htm.

IPECE (Instituto de Pesquisa e Estratégia Econômica do Ceará). 2016. Instituto de Planejamento do Estado do Ceará, Perfil Básico Municipal: Crato. Governo do Estado do Ceará, Secretaria do Planejamento e Coordenação. Eletronic Database accessible at http:// www.ipece.ce.gov.br/ perfil_basico_municipal/2016/ Crato.pdf. Captured on 04 January 2016.

King, R. B. 1989. Sexual dimorphism in tail length: sexual selection, natural selection, or morphological constraint? Biological Journal of Linnean Society 38: 133-154.

Klauber, L. M. 1972. Rattlesnakes, Their Habits, Life Histories, and Influence on Mankind. $2^{\text {nd }}$ Edition. Berkeley. University of California Press. 1534 pp.

Lillywhite, H. B. 1987. Temperature, energetics, and physiological ecology. Pp. 422-477 in R. A. Seigel, J. T. Collins, and S. S. Novak (eds.), Snakes: Ecology and Evolutionary Biology. New York. McMillan Publishing Company.

Lima, F. F., J. R. M. Feitosa, F. Santos, S. M. Pereira, A. A. F. Saraiva, T. R. Benedikt, J. P. P. Melo, and F. I. Freitas. 2012. Geopark Araripe: Histórias da Terra, do Meio Ambiente e da Cultura. Governo do Estado do Ceará, Secretaria das Cidades, Projeto Cidades do Ceará Cariri Central. 85 pp.

Loebmann, D., S. C. Ribeiro, D. L. Sales, and W. O. Almeida. 2009. New records of Atractus ronnie (Serpentes, Colubridae) in relictual forest from the state of Ceará, Brazil, and comments on meristic and morphometric data. Biotemas 22: 169-173.

Marques, O. A. V., A. Eterovic, and I. Sazima. 2004. Snakes of the Brazilian Atlantic Forest: An Illustrated Field Guide for the Serra do Mar Range. Ribeirão Preto. Holos Editora.

Martins, M. and M. E. Oliveira. 1993. The snakes of genus Atractus Wagler (Reptilia: Squamata: Colubridae) from the Manaus region, central Amazonia, Brazil. Zoologische Mededelingen 67: 21-40.

Martins, M. and M. E. Oliveira. 1998. Natural history of snakes in forests of the Manaus region, Central Amazonia, Brazil. Herpetological Natural History 6: 78-150.
MMA (Ministério do Meio Ambiente). 2014. Lista Nacional Oficial de Espécies da Fauna Ameaçadas de Extinção. Portaria No-444, de 17 de dezembro de 2014. Eletronic Database accessible at http://www.icmbio.gov.br/portal/ images/stories/biodiversidade/fauna-brasileira/avaliacaodo-risco/PORTARIA_No_444_DE_17_DE_ DEZEMBRO_DE_2014.pdf. Captured on 16 October 2015.

Myers, C. W. 2003. Rare snakes-five new species from eastern Panama: reviews of Northern Atractus and Southern Geophis (Colubridae: Dipsadinae). American Museum Novitates 3391: 1-47.

Pagel, M. D. and P. H. Harvey. 1989. Comparative methods for examining adaptation depend on evolutionary models. Folia Primatologica 53: 203-220.

Passos, P. and R. Fernandes. 2008. A new species of colubrid snake genus Atractus (Reptilia: Serpentes) from central Amazon. Zootaxa 1849: 59-66.

Passos, P., R. Fernandes, and N. Zanella. 2005. A new species of Atractus (Serpentes: Colubridae) from southern Brazil. Herpetologica 61: 209-218.

Passos, P., D. S. Fernandes, and D. M. Borges-Nojosa. 2007. A new Species of Atractus (Serpentes: Dipsadinae) from a relictual forest in Northeastern Brazil. Copeia 2007: 788-797.

Passos, P., M. Dobiey, and P. J. Venegas. 2010. Variation and natural history notes on giant groundsnake, Atractus gigas (Serpentes: Dipsadidae). South American Journal of Herpetology 5: 73-82.

Passos, P., L. Y. Echevarría, and P. J. Venegas. 2013. Morphological variation of Atractus carrioni (Serpentes: Dipsadidae). South American Journal of Herpetology 8: 109-120.

Passos, P., A. Martins, and D. Pinto-Coelho. 2016. Population morphological variation and natural history of Atractus potschi (Serpentes: Dipsadidae) in northeastern Brazil. South American Journal of Herpetology 11: 188-211.

Passos, P., A. L. C. Prudente, L. O. Ramos, J. R. CaicedoPortilla, and J. D. Lynch. 2018. Species delimitations in the Atractus collaris complex (Serpentes: Dipsadidae). Zootaxa 4392: 491-520.

Pérez-Santos, C. and A. G. Moreno. 1990. Anotaciones biométricas y alimenticias de la serpiente neotropical Atractus badius (Boie, 1827) de la colección del Museo Nacional de Ciencias Naturales de Madrid. Revista Española de Herpetologia 4: 9-15.

Peters, J. A. 1964. Dictionary of Herpetology. New York. Hafner Publishing. 426 pp. 
Pizzatto, L., S. M. Almeida-Santos, and O. A. V. Marques. 2007. Biologia reprodutiva de serpentes brasileiras. Pp. 201-221 in L. B. Nascimento and M. E. Oliveira (eds.), Herpetologia no Brasil II. Belo Horizonte. Sociedade Brasileira de Herpetologia.

Resende, F. C. and L. B. Nascimento. 2014. The female reproductive cycle of the Neotropical snake Atractus pantostictus (Fernandes \& Puorto, 1993) from southeastern Brazil. Anatomia, Histologia, Embryologia 44: $225-235$.

Ribeiro, S. C., I. J. Roberto, D. L. Sales, R. W. Ávila, and W. O. Almeida. 2012. Amphibians and reptiles from the Araripe bioregion, northeastern Brazil. Salamandra 48: $133-146$.

Santos-Costa, M. C., G. F. Maschio, and A. L. C. Prudente. 2015. Natural history of snakes from Floresta Nacional de Caxiuanã, eastern Amazonia, Brazil. Herpetology Notes 8: 69-98.

Savage, J. M. 1960. A Revision of the Ecuadorian Snakes of the Colubrid Genus Atractus. Michigan. Miscellaneous Publications of the Museum of Zoology, University of Michigan, no. 112.86 pp.

Sawaya, R. J., O. A. V. Marques, and M. Martins. 2008. Composição e história natural das serpentes de Cerrado de Itirapina, São Paulo, sudeste do Brasil. Biota Neotropica 8: 127-149.

Shine, R. 1977. Reproduction in Australian elapid snakes. II. Female reproductive cycles. Australian Journal of Zoology 25: 655-666.

Shine, R. 1978. Growth rates and sexual maturation in six species of Australian elapid snakes. Herpetologica 34: $73-79$.
Shine, R. 1984. Ecology and small fossorial australian snakes of the genera Neelaps and Simonelaps (Serpentes, Elapidae). University of Kansas Museum of Natural History, Special Publication 10: 173-183.

Shine, R. 1986. Ecology of a low-energy specialist: food habits and reproductive biology of the arafura filesnake (Acrochordidae). Copeia 1986: 424-437.

Shine, R. 1988. Food habitats and reproductive biology of small Australian snakes of genera Unechis and Suta (Elapidae). Journal of Herpetology 22: 307-315.

Shine, R. 1991. Strangers in a strange land: ecology of the Australian colubrid snakes. Copeia 1991: 120-131.

Shine, R. 1994. Sexual size dimorphism in snakes revisited. Copeia 1994: 326-346.

Sousa, J. G. G. and R. W. Ávila. 2015. Body size, reproduction and feeding ecology of Pleurodema diplolister (Amphibia: Anura: Leiuperidae) from Caatinga, Pernambuco state, Northeastern Brazil. Acta Herpetologica 10: 129-134.

Tabarelli, M. and A. M. M. Santos. 2004. Uma breve descrição sobre a história natural dos brejos nordestinos. Pp. 17-24. In K. C. Pôrto, J. J. P. Cabral, and M. Tabarelli (eds.), Brejos de Altitude em Pernambuco e Paraíba, História Natural, Ecologia e Conservação. Brasília. Ministério do Meio Ambiente.

Zaher, H., I. Souza, D. J. Gower, E. Hingst-Zaher, and N. J. Silva Jr. 2005. Redescription of Atractus albuquerquei (Serpentes: Colubridae: Dipsadinae), with comments on geographical distribution and intraspecific variation. Papéis Avulsos de Zoologia 45: 19-32.

Editor: Francisco Luís Franco 